\title{
Identification of Learning Difficulties in Children at Early Childhood Education
}

\author{
Isabella Hasiana \\ Faculty of teacher training and education, PGRI Adi Buana Surabaya University, Indonesia \\ Corresponding e-mail: icha1916@yahoo.co.id
}

\begin{abstract}
Since early childhood, children are already confronted with the ability to learn a variety of behaviors that are part of the development and ripeness. Learning is the process of Foundation of the development of human life which must be traversed. Learn not just experience. Learning is a process rather than an outcome, because it takes place actively and thoroughly by using various forms of works to achieve the goal. Not uncommon in the learning process, individuals find it difficult that certainly could not be considered small. This is because children who have difficulty learning from an early age can affect the development of their learning process in the next age. Hence the importance of conducting identification of learning difficulties experienced so that we as educators or parents can cope with it. This research is the study of literature to expose the learning difficulties experience by early childhood and early identification.
\end{abstract}

Keywords: learning difficulties, early childhood

\section{INTRODUCTION}

Learning is a process which cannot be separated from human life. Each individual will experience called the learning process. Learning can be done in formal and non-formal. On early childhood education, conducted since the child at an early age is the basis for the formation of personality and it played an important role which will determine the development of the child in the future. Law No. 20 of 2003 on the national education system Chapter 1 article 1 Clause 2 stated that early childhood education (PAUD) is a coaching effort devoted to children from birth up to the age of 6 years are done through the awarding of educational stimulation to help the growth and development of physical and spiritual so that children have preparedness in entering further education.

But it is certainly offset by the maturity in the aspect of development. This is very important because it will know the growing swell of a child when it will enter the world of education so that later would have no trouble in the future.

The fact that happens, parents often worry that their children will not be able to follow the learning because experience difficulties in learning. Therefore, it is important for us as parents and teachers to identify about learning difficulties experienced by early childhood.
Basically, the process of learning in kindergarten is not a learning process that is damning. This means that children are required to learn reading, writing and counting. So, the expectation at the time a child enters primary school, the ability to read, write and count has been exceeded. Of course, it is becoming a problem.

Education in kindergartens can help develop various potentials both psychic and physical which includes moral and religious values, social emotional, cognitive, motor, language, physical independence and art to enter primary education. Organizing programs, early childhood education and kindergarten that corresponds with the level of maturity of the acquisition in children, including the development of habits of basic capabilities (Morison, 2012), where the basic capabilities have minimal targets to be achieved by the child. However, sometimes the children have difficulty in reaching such targets thus experiencing difficulties. Learning difficulties that occur during development, is a process of learning that is concerned with the development tasks be solved completely when at an early age, then it will have no effect on the further development, as in the process of learning in the academic field after the child enters school (Jamaris, 2014). 
Children who have difficult of learning either in general or specifically require a special service in the process of his education at the school. They need guidance and programs that fit the needs of their learning. Specific guidance will be of great help in the completion of student learning problems caused by psychological factors. While children with specific learning difficulties need special programs in the form of individual learning programs

\section{LEARNING DIFFICULTIES}

The notion of learning difficulties often used erroneously in everyday life. Many people mostly cannot distinguish between learning difficulties, slow learning and mentally disabled. It would, we need to understand about the understanding of learning difficulties in order to make education policy for those who experience it and be able to determine effective mitigation strategies and efficiently.

Learning difficulties is the translation of the term United Kingdom namely learning disability is a disorder that makes the individual concerned is difficult to perform learning activities effectively. Learning difficulties is also very closely related to academic results and achievements are also daily activities. Learning difficulties are not directly related to the level of intelligence of the individual who have difficulties, but these individuals have difficulty in mastering the skills of learning and in carrying out specific tasks required in learning such as is done in conventional learning methods and approaches.

The definition quoted from Suryani, (2010): specific learning difficulties is a disorder in one or more of the psychological processes that include understanding and use of the language of the speech or writing. The disorder may be appeared in the form of listening, thinking, speaking, reading, writing, spelling, or counting.

Children are said to be experiencing learning difficulties is impaired for one or more of the basic process that includes the use of understanding spoken language or text where the disorder may appear in the form of imperfect abilities in listening, thinking, speaking, reading, writing, spelling or calculating (Subini, 2015).

\section{CLASSIFICATION OF LEARNING DIFFICULTIES}

In conducting classification learning difficulties is not easy because it is a heterogeneous group of difficulties. Learning difficulties has many types, each of which requires a diagnosis and program supply role. But still needs to be done because the classification is useful for determining the proper learning strategy (Abdurrahman, 2012).

Generally, according in Suryani (2010) learning difficulties can be classified into two groups, (1) learning difficulties related to development (developmental learning disabilities) and (2) the academic learning difficulties (academic learning disabilities).

Learning difficulties related to development (Developmental Learning Disabilities), divided into: (a). Attention (attention disorder). The child with attention disorder will respond on various stimulus. These children are always moving, frequently distracted his attention cannot sustain attention long enough to learn and cannot focus completely on it; (b). Memory Disorder is the inability to remember what has been seen or heard or experienced. Children with visual memory problems may have difficulty in recalled the words that are displayed visually. A similar case is also experienced by children with problems in memory of the auditory who influenced the development of the language lisanny; (c). Disorders of visual perception and motor. Children with impaired visual perception cannot understand the signs-traffic signs, arrow, words written and visual symbols to another. They could not catch the meaning of a figure or figures or have the knowledge of him; (d). Thinking Disorder is difficulty in cognitive operations on a troubleshooting the formation of concepts and associations. Thinking disorder closely related to disturbances in verbal language; (e). Language Disorder is the most common learning difficulties experienced in children pre-school. Usually these kids don't talk or respond properly against the instructions or verbal statement.

From the above discussion, it can be concluded that learning difficulties are associated with the development of motor disorders and includes perception, language learning and communication difficulties, learning difficulties and in the adjustment of social behavior.

Academic Learning Difficulties (Academic Learning Disabilities) are the conditions that inhibit the learning process that is in reading, spell, write or calculate. This inability to appear by the time the child showing performance under their academic potential. Academic learning difficulties also point to the existence of failure - failure of the appropriate academic achievement with expected capacity (Abdurrahman, 2012).

Academic learning difficulties can be known by teachers or parents when a child displays one or more academic ability. On the contrary, learning 
difficulties are generally hard to known good development by parents as well as by teachers because of the absence of systematic measurementsmeasurements as well as in academics. Moreover, it can also be argued that learning difficulties are associated with the development of often regarded as learning difficulties caused not mastered skills prerequisite (prerequisite skills), that is a skill that must be mastered before in order to master the skills of the next form.

In addition to the classification is divided into learning difficulties associated with the development and academic learning difficulties, learning difficulties in further detail can be classified as follows (Suryani, 2010).

Development of learning difficulties (preacademic). The difficulty is the development include; (a). Motor development Disorders (motion), namely disorders of the ability in doing motion and coordination tool motion. The form includes: fine motor gross motor, body, spatial understanding appreciation and lateralization (directions); (b). Sensory development Disorder (sensing), is a disturbance in the ability capture the stimulation from the outside through the sensory tools that cover the process of vision, hearing, smell, sensor and taster; (c) Perceptual development Disorder (understanding or what of sense), namely disorders of the ability to process and understand its sense of sensing process so that it becomes meaningful information; (d) Developmental Disorder behavior, i.e. interference on the ability to organize and control the internal nature of the self within. Such disorders include: ADD (Attention Deficit Disorder) or ADHD and attention disorders (Attention Deficit Hyperactivity Disorder) or disturbance of attention that accompanied the hyperactivity.

Academic Learning Difficulties include, (a). Dyslexia or difficulty reading is difficult to interpret symbols, letters and numbers through visual perception and auditory. Where this will have an impact on the ability of reading comprehension; (b) Dysgraphia or difficulty writing are difficulties involving the process of drawing symbols sound became a symbol of the letters or numbers. Trouble writing occurs at some stage of the activity of writing, i.e., spelling, writing beginning, and advanced/expressive writing/composition; (c) Dyscalculia or the difficulty of Counting is the difficulty in using the language the symbol for thinking, noted, and communicate ideas with regard to quantity or amount (Murtadlo,2013).

\section{CAUSES OF LEARNING DIFFICULTIES}

The main causes of learning difficulties (learning disabilities) are internal factors, namely the possibility of neurological dysfunction.

Neurological dysfunction often cause difficulties not only learning but can also lead to emotional disorders and mentally disabled. A variety of factors that can cause neurological dysfunction that would later can lead to learning difficulties, among others, is a genetic factor (1), (2) brain injury due to physical trauma or due to lack of oxygen, (3) Biochemistry is missing (e.g. biochemical needed to enable nerve center), (4) biochemistry that can damage the brain (e.g. dye substances in foods), (5) environmental pollution (e.g. leaching of lead), (6) inadequate nutrition, and (7) influences an adverse psychological and social development of children (environmental deprivation). All of these factors cause learning difficulties may cause the disorder of mild to severe categories (Abdurrahman, 2012).

Moreover, it can also specifically have mentioned some causes of learning difficulties found in the literature and research results (Suryani, 2010), is a (1). Heredity/congenital; (2).The disorder during pregnancy, during childbirth or premature; (3). The condition of the fetus does not receive enough oxygen or nutrients and or mothers who smoke, use drugs (drugs), or drank alcohol during pregnancy; (4). Post-birth Trauma, such as a very high fever, head trauma, or ever sank; (5) Recurring ear infections in infancy and toddlers. Children with learning difficulties are usually have a weak immune system; (6) Early childhood that are often associated with aluminum, arsenic, mercury/mercury, neurotoxin and others.

Research shows that what happens during the early years of the pregnancy until the age of 4 years is a critical period on learning in the future. Stimulation in infancy and cultural conditions also affect the learning of the child. In the early days of the birth until the age of 3 years for example, children learn the language by way of listening to the song, speaking to him, or a relation of the story. In some cases, if the interaction is less done then it can contribute to the lack of ability that makes children child phonology be difficult reading (Suryani, 2010). 


\section{IDENTIFICATION OF LEARNING DIFFICULTIES IN CHILDREN, EARLY CHILDHOOD EDUCATION}

Identification in this case is the process to locate and identify individuals in order to obtained information about the types of learning difficulties faced by getting the right information in providing appropriate education services strategy. In addition, the identification of learning difficulties is also to anticipate the confusion in the classification of learning difficulties experienced by children.

Assessment service is a process of gathering information about a child that will be used to create consideration and decisions related to the child (Abdurrahman, 2012:30). The main purpose of the assessment is to obtain information that can be used as consideration in a plotting program for difficult of learning.

According to Hargrove and Poteet (Abdurrahman, 2012:30), the assessment is one of the three education evaluation activity. The third activity is (1)

assessment, (2), (3) diagnostic prescriptive. Thus, the assessment can be done to enforce the diagnosis and the diagnosis is made based on prescripts which is in the form of actual is in the form of an individualized education program (individualized education programs) (Suryani, 2010:13), and the assessment should reveal the identification of students who are having difficulty learning conducted by a team from different disciplines. It is important to do so that we can appropriately classifying forms of learning difficulties experienced by children.

School Psychologist: get information about the condition of the family, social and culture, measuring intelligence and behavior through the standardized measuring instrument, and gain an overview of the advantages and disadvantages of students; Classroom teacher and parents: provide information about child development, skills that have been retrieved children, his motivation, his attention span, social acceptance, and social adjustment, which can be obtained by completing the rating scale about the behavior of children; Expert education for children in need of special academic assessment: conduct using various individual tests, observing the student in the learning situation and play, see the results of the work of the students, and discuss the performance of students with teachers and parents; Nursing School: obtain data about the development of student health. Nurses could ask students to demonstrate a simple motor activity, perform hearing tests and visions of students; School administrators: facilitating meetings with relevant parties and providing funds. Sometimes it also involves other parties such as the gym teacher, speech therapist, occupational therapist, social worker or even a pediatrician.

\section{CONCLUSION}

Maturity and learning is an important part in the development of a child. The maturity associated with readiness for the proper functioning of the psychophysical individuals influenced by innate properties of the individual. While the study is the development that comes from practice and effort on the part of the individual. In the process, individuals sometimes have difficulty in learning the classified outline is learning difficulties associated with the development and academic learning difficulties.

To be able to classify learning difficulties experienced by individuals, needed assessment and cooperation team consisting of various disciplines. In order to do a proper classification and determine the appropriate education services strategy.

\section{REFERENCES}

Abdurrahman (2012). Ana Berkesulitan Belajar: Teori, Diagnosis, dan Remediasinya. Jakarta Agustin dan Nurihsan (2011). Dinamika

Perkembangan Anak dan Remaja: Tinjauan

Psikologi, Pendidikan, dan Bimbingan. Bandung

Jamaris (2014). Kesulitan Belajar: Perspektif, Asesmen, dan Penanggulangannya Bagi Anak Usia Dini dan Usia Sekolah. Bogor

Morrison (2012). Dasar-Dasar Pendidikan Anak Usia Dini. Jakarta

Murtadlo. 2013. Edu-Math, Vol 4, 38-45

Suryani. September 2010, 33-37, Magistra No 73 Th. XXII pp. 0215-9511

Subini. 2015. Mengatasi Kesulitan Belajar Pada Anak. Yogyakarta 